\title{
Clinical Evaluation of a Dermic Allograft in Procedures to Increase Attached Gingiva Width
}

\author{
Ésio de Oliveira VIEIRA \\ Rivail Antonio Sergio FIDEL JUNIOR \\ Carlos Marcelo da Silva FIGUEREDO \\ Ricardo Guimarães FISCHER
}

Department of Integrated Clinical Procedures, Discipline of Periodontology, Rio de Janeiro Dental School,
State University of Rio de Janeiro, Rio de Janeiro, RJ, Brazil

\begin{abstract}
The aim of this study was to clinically evaluate the use of alloderm to increase the width of attached gingiva. Nine patients were selected. The inclusion criteria were: attached gingiva smaller than $1 \mathrm{~mm}$; Miller's class I and II gingival recession; patients able to attend control dental appointments; absence of periodontal pocket and endodontic treatment in the neighboring area where the acellular dermal graft would be placed. The clinical evaluation included: allograft shrinkage 7, 14, 21, 30, 60 and 90 days after surgery; width of attached gingiva at the end of the study; difference in color and mobility of allograft. Allograft shrinkage was calculated by comparing its area immediately after surgery to its areas in the other days. Five standardized photographs were taken, digitized and the allograft area was measured. Paired Student's t-test was used to compare the clinical data $(\alpha=0.05)$. The mean allograft shrinkage 90 days after surgery was $90.43 \%$ and the mean width was $1.27 \mathrm{~mm}$. Difference in color was observed in only 1 subject and no allograft mobility was detected. The results showed a large shrinkage of allograft 90 days after its insertion, raising doubts as to its validity for increasing the width of attached gingiva.
\end{abstract}

Key Words: dermic allograft, increase of attached gingiva.

\section{INTRODUCTION}

The width of attached gingiva necessary to maintain gingival health is minimal $(1,2)$. However, there are cases where it should be increased. For these situations the surgical procedures most frequently used are free gingival grafts and pediculated grafts. The problems for these procedures include a need of a donor area $(3,4)$, that may increase the surgical time, loss of attachment of the donor area, bleeding during and after surgery and pain (5).

An acellular dermal graft was used in Periodontology as an alternative treatment for mucogingival surgical procedures (6-8). It seems that this acellular dermal graft present no chance of virus transmission, making it acceptable to the patients $(9,10)$. The graft is immunologically inert, acting as an arquitetonic structure, supporting the migration of fibroblasts and revascularization. The basal membrane is maintained to facilitate the migration and retention of epithelial cells.
The acellular graft has been used to increase mucosal width around implants and as a substitute of gingival free grafts in surgical procedures for increasing the width of attached gingiva (11). One problem that may hinder the use of the acellular graft would be an excessive shrinkage (12). The free gingival graft shrinkage varies between 30 and 50\% (13). However, there is no study evaluating how the acellular graft would shrink over time. Therefore, the aim of the present study was to clinically evaluate the use of an acellular dermal graft to increase the width of attached gingival.

\section{MATERIAL AND METHODS}

Nine patients ( 5 males and 4 females) aged 26 to 59 years (mean age $=42.4 \pm 9.9$ years) were selected from the Periodontal Clinic of the Brazilian Dental Association, Rio de Janeiro, Brazil. All patients received periodontal treatment, including oral hygiene instructions, supragingival and subgingival scaling and root 
planing. The surgeries were performed 30 days after these procedures. The inclusion criteria were: 1 . Patients with attached gingiva width smaller than $1 \mathrm{~mm} ; 2$. Patients with Miller's Class I and II gingival recession, with attached gingiva adjacent to the recession area smaller than $1 \mathrm{~mm} ; 3$. Patients that could attend a regular program of maintenance, and 4. Absence of periodontal pocket and endodontic treatment at the adjacent areas of the graft. The exclusion criteria were: 1 . Patients with history of allergy to penicillin, neomycin, streptomycin, gentamycin, kanomycin; 2. Patients with systemic diseases that could interfere with a proper healing after surgery; and 3. Smokers.

The following clinical parameters were examined by a calibrated examiner: plaque Index (PI); gingival index (GI); probing pocket depth (PPD); probing attachment level (PAL); and width of attached gingiva, considered as the distance from the gingival margin to the mucogingival sulcus minus the PPD. PPD and PAL were measured with a calibrated Williams's periodontal probe (Hu-Friedy, Chicago, IL, USA). Measurements of PI, GI and PPD were repeated 60 and 90 days after surgery. Reinforcement of oral hygiene techniques was performed as necessary.

The preparation of the recipient bed was done in the following way: with a size 15 scalpel blade (Med Blade/Embramed, Jurubatuba, SP, Brazil) mounted in a Bard/Parker scalpel handle, an incision was made at the level of the mucogingival line. The mesiodistal width of this first incision was $20 \mathrm{~mm}$. From the extremities of the horizontal incision, vertical incisions were made in direction to the deep vestibule with $10 \mathrm{~mm}$ of extension. These measures correspond to the standard measures of the dermic allograft informed by the manufacturer. The periosteum was preserved by a split-thickness flap and the mucous tissue was removed with Goldman Fox-type surgical scissors (Neumar Instrumentos Cirúrgicos Ltda., Caieiras, SP, Brazil). A periostal fenestration was made in the apical edge of the surgical bed and mucoeriostal sutures were placed below the fenestration using a 4.0 silk suture (Ethicon/Jonhson \& Jonhson, São José dos Campos, SP, Brazil).

The acellular graft (LifeCell Corporation; The Woodlands, TX, USA) was hydrated according to the manufacturer's instructions, accomodated on the receptor area, and gently pressed with wet gauze for $5 \mathrm{~min}$, until difficulty to move the graft was felt. The graft was sutured to the receptor area with 4.0 silk sutures (Ethicon/
Jonhson \& Jonhson). Surgical dressing without eugenol (Coepak; GC America Inc., Alsip, IL, USA) was placed over the graft. Patients were instructed to rinse twice a day with a $0.12 \%$ chlorhexidine solution (Periogard; Colgate/Palmolive, São Paulo, SP, Brazil) for 14 days. Amoxicilin (Amoxil; GlaxoSmithKline, Rio de Janeiro, RJ, Brazil), $500 \mathrm{mg}, 3$ times a day, was prescribed to the patients for 10 days. The surgical dressing was changed after 7 days and removed after 14 days. Sutures were removed after 14 days.

Five photographs were taken from the allografts by the same operator in a standardized way, immediately and 7, 14, 21, 30, 60 and 90 days after the grafting procedure. The photographs were digitized using a flatbed scanner (TCE S 440; TCE São Paulo, SP, Brazil) connected to a computer, using the Microsoft Photo Editor software. The definition pattern was the same for all photographs (width 15.24 and height 10.17). The images were analyzed using Scion image-analysis software for Windows (Scion Corporation, Frederick, MD, USA). The area of the allografts was measured in $\mathrm{cm}^{2}$, and a mean value of the 5 images was calculated for each period analyzed for each patient. The percentage of shrinkage was calculated from the area measured immediately after surgery, for each patient. Mobility of the allograft was detected with lateral movements of the periodontal probe in a horizontal position in relation to the allograft, 90 days after the surgery. The discrepancy of the color related to the neighboring area (pale, similar or reddish) was observed at all period times. The width of the attached gingiva was measured 60 and 90 days after surgery. Student's t-test for paired samples was used to compare the means of the clinical measurements at all experimental periods. $\mathrm{P}$ value was considered as 0.05 .

\section{RESULTS}

The values of PI, GI, PPD, PAL and width of attached gingiva are presented as "mean (standard deviation)". The mean PI before surgery and on day 90 was $22 \%$ (2.9) and 19\% (3.4), respectively. For GI, these values were $0.5(1.0)$ and $0(0.0)$, respectively. No statistically significant differences ( $p>0.05$ ) were found for these values. Mean PPD was $1 \mathrm{~mm}(0.4)$ before surgery, and it remained the same during the 90 day period. Mean PAL was $5.4 \mathrm{~mm}(1 \mathrm{~mm})$ before surgery and $5.3 \mathrm{~mm}$ $(1 \mathrm{~mm})$ on day 90 . The mean attached gingiva width at the end of the study was $1.3 \mathrm{~mm}(0.6 \mathrm{~mm})$. There was 
no allograft mobility, and only 1 patient presented color discrepancy at the end of the study.

The mean percentage and standard deviation of allograft shrinkage obtaited for the 9 patients in each evaluation period was as follows: 7 days: 17.4 (12.2); 14 days: 35.4 (14.7); 21 days: 57.2 (7.8); 30 days: 69.8 (12.7); 60 days: 89.5 (4.9); 90 days: 90.4 (4.9). It may be observed that the shrinkage increased significantly during the healing period, with the highest contraction observed on day 60 . The mean area of the acellular dermal graft showed a significant decrease along the course of the study, as shown in Table 1.

\section{DISCUSSION}

A narrow area of attached gingiva may be related to difficulties to maintain gingival health (14). However, human studies showed that periodontal health may be maintained with attached gingiva smaller than $1 \mathrm{~mm}$ (2). The presence of narrow areas of attached gingival is not correlated to severity of gingival inflammation, tendency to gingival recession increase, or higher levels of plaque and gingival indexes $(1,2)$. On the other hand, increase of width of attached gingiva may be indicated in situations such as dehiscence related to orthodontic movements, improvement of personal plaque control, and use of fixed or removable dentures.

The procedure most likely indicated to increase the width of attached gingival is free gingival graft $(2,5,13)$. It is a reliable procedure, and graft shrinkage is around $35 \%$. However, it may have some problems, such as the need for a donor area with sufficient dimensions to remove a graft, two surgical areas with a possibility of increasing pain after surgery, and a longer time of surgery. An alternative surgery for this procedure would be the use of an acellular dermic graft (15). That would avoid the preparation of a donor area, and consequently, less pain after surgery and a faster surgical procedure (1619). Alloderm is an acellular dermic allograft, processed after human skin, transported in a medium containing penicilin, streptomicin, kanamicin and neomicin. Even after washing, traces of these antibiotics may be found. Viral transmission has been excluded (2).

The results of the present study showed a gradual increase of allograft shrinkage. On day 7, there was $17.2 \%$ shrinkage versus $89.5 \%$ on day 60 . On day 90 , the contraction reached its highest level. These results are somewhat higher than the $71 \%$ shrinkage observed by Wei et al. (12).

The mean width of attached gingiva at the end of the study was $1.27 \mathrm{~mm}$, similar to the results observed by Harris (9) and Tal (20). These authors showed an increase of attached gingival between 1 and $2 \mathrm{~mm}, 4$ to 8 months after the acellular graft surgery. However, our results are smaller than those obtained by Callan (1), which showed 5 to $12 \mathrm{~mm}$ of attached gingival gain. Callan used the acellular dermal graft around implants, and evaluated them only after 30 days. In the present study, the greatest shrinkage occurred between days 30 and 90. Greater shrinkage could be observed in Callan's study if a longer evaluation period were used.

In two patients, there was a 2 mean gain of clinical attachment of $1 \mathrm{~mm} 60$ days after surgery. This result may be related to a possible advance of the allograft in a coronal position. The creeping attachment has been observed also after free gingival grafts cicatrization (18).

At 30 days, 5 patients presented the acellular dermal graft with similar color and shape of the neighboring sites, while on day 60th all 9 patients presented similar color and shape. Silverstein and Callan (10) observed color differences until the 10th day after surgery, with excellent color and shape matching 6 weeks after sur-

Table 1. Mean area and standard deviation (SD) of the allograft $\left(\mathrm{cm}^{2}\right)$ immediately and 7, 14, 21, 30, 60 and 90 days after surgery (n=9).

\begin{tabular}{|c|c|c|c|c|c|c|c|}
\hline Allograft area & $\begin{array}{l}\text { Immediately } \\
\text { after surgery }\end{array}$ & 7 days & 14 days & 21 days & 30 days & 60 days & 90 days \\
\hline Mean (SD) & $40.0(8.6)$ & $33.1^{1}(8.8)$ & $26.0^{2}(8.0)$ & $19.7^{3}(6.9)$ & $12.9^{4}(6.6)$ & $4.4^{5}(1.9)$ & $3.9^{6}(1.8)$ \\
\hline
\end{tabular}

$1=$ Statistically significantly difference from IAS; ${ }^{2}=$ Statistically significantly difference from day $7 ;{ }^{3}=$ Statistically significantly difference from day $14 ;{ }^{4}=$ Statistically significantly different from day $21 .{ }^{5}=$ Statistically significantly different from day $30 ;{ }^{6}=$ Statistically significantly different from day 60 . 
gery using the acellular dermal graft. The contraction of the acellular dermal graft increased significantly over time, with the highest clinical shrinkage observed on day 60. In conclusion, the use of an acellular dermal graft for procedures to increase the width of attached gingiva seems to be questionable because of the high allograft shrinkage occurred within 90 days after the grafting procedure.

\section{RESUMO}

O objetivo do presente estudo foi avaliar clinicamente o uso do Alloderm no aumento da faixa de gengiva inserida. Nove pacientes foram selecionados. Os critérios de inclusão foram: pacientes com faixa de gengiva inserida menor que $1 \mathrm{~mm}$; recessão gengival classe I e II de Miller; pacientes com possibilidade de freqüentar as consultas de controle; ausência de bolsa periodontal e tratamento endodôntico nas áreas adjacentes onde o enxerto dérmico acelular será usado. A avaliação clínica incluiu: contração do aloenxerto $7,14,21,30,60$ e 90 dias após a cirurgia; faixa de gengiva inserida obtida no fim do estudo; diferença de coloração em relação aos tecidos adjacentes; mobilidade do aloenxerto 90 dias após a cirurgia. A contração do aloenxerto foi calculada comparando a área imediatamente após a cirurgia com as áreas dos outros dias. Cinco fotos padronizadas foram tiradas dos estágios analisados, escaneadas e a área mensurada. $\mathrm{O}$ teste $t$ de Student foi usado para comparar os dados clínicos $(\mathrm{p}<0,05)$. A média de contração 90 dias após a cirurgia foi de $90,43 \%$, faixa de gengiva inserida de 1,27 mm. Diferença de cor foi observada em um paciente e nenhuma mobilidade foi detectada. Os resultados mostraram uma grande contração do aloenxerto 90 dias após sua inserção, gerando dúvidas sobre sua validade no aumento da faixa de gengiva inserida.

\section{REFERENCES}

1. Callan DP. Use of acellular dermal matrix allograft material in dental implant treatment. Dental Surgery Products 1996;1:14-17.

2. Hansbrough JF, Franco ES. Skin replacements. Wound healing: state of the art. Clin Plast Surg 1998;10:407-422.

3. Gapski R, Parks CA, Wang HL. Acellular dermal matrix for mucogingival surgery: a meta-analysis. J Periodontol 2005;76:18141822.

4. Souza SL, Novaes AB Jr, Grisi DC, Taba M Jr, Grisi MF, de Andrade PF. Comparative clinical study of a subepithelial connective tissue graft and acellular dermal matrix graft for the treatment of gingival recessions: six- to 12 -month changes. J Int Acad Periodontol 2008;10:87-94.
5. Hall WB. The current status of mucogingival problems and their therapy. J Periodontol 1981;52:569-575.

6. Barros RR, Novaes AB, Grisi MF, Souza SL, Taba MJ, Palioto DB. New surgical approach for root coverage of localized gingival recession with acellular dermal matrix: a 12-month comparative clinical study. J Esthet Restor Dent 2005;17:156-164.

7. Fowler EB, Francis PO, Goho C. Use of acellular dermal matrix allograft for management of inadequate attached gingiva in a young patient. Mil Med 2003;168:261-265.

8. Novaes AB Jr, de Barros RR. Acellular dermal matrix allograft. The results of controlled randomized clinical studies. J Int Acad Periodontol 2008;10:123-129.

9. Harris RJ. Root coverage with a connective tissue with partial thickness double pedicle graft and an acellular dermal matrix graft: a clinical and histological evaluation of a case report. J Periodontol 1998;69:1305-1311.

10. Silverstein LH, Callan DP. An acellular dermal matrix allograft substitute for palatal donor tissue. Postgrad Dent 1996;3:14-21.

11. Scarano A, Barros RR, Iezzi G, Piattelli A, Novaes AB Jr. Acellular dermal matrix graft for gingival augmentation: a preliminary clinical, histologic, and ultrastructural evaluation. J Periodontol 2009;80:253-259.

12. Wei PC, Laurrel L, Geivelis M, Lingen MW, Maddalozzo D. Acellular dermal matrix allografts to achieve increased attached gingiva. Part 1. A clinical study. J Periodontol 2000;71:1297-1305.

13. Haghighati F, Mousavi M, Moslemi N, Kebria MM, Golestan B. A comparative study of two root-coverage techniques with regard to interdental papilla dimension as a prognostic factor. Int J Periodontics Restorative Dent 2009;29:179-189.

14. Maynard GJ, Wilson RDK. Physiologic dimensions of the periodontium significant to the restorative dentistry. J Periodontol 1979;50:170-174.

15. Chambrone L, Chambrone D, Pustiglioni FE, Chambrone LA, Lima LA. Can subepithelial connective tissue grafts be considered the gold standard procedure in the treatment of Miller Class I and II recession-type defects? J Dent 2008;36:659-671.

16. Allen EP. Alloderm: an effective alternative to palatal donor tissue for treatment of gingival recession. Dent Today 2006;25:50-52.

17. Harris RJ. A short-term and long-term comparison of root coverage with an acellular dermal matrix and a subepithelial graft. J Periodontol 2004; 75:734-743.

18. Hirsch A, Goldstein M, Goultschin J, Boyan BD, Schwartz Z. A 2-year follow-up of root coverage using sub-pedicle acellular dermal matrix allografts and subepithelial connective tissue autografts. J Periodontol 2005;76:1323-1328.

19. Santos A, Goumenos G, Pascual A. Management of gingival recession by the use of an acellular dermal graft material: a 12-case series. J Periodontol 2005;76:1982-1990.

20. Tal H. Subgengival acellular dermal matrix allograft for the treatment of gingival recession. J Periodontol 1999;70:1118-1124.

Accepted August 11, 2009 